\title{
Signet Ring Lobular Carcinoma in Situ as a Part of the "Rosen Triad" (Tubular Carcinoma, Columnar Cell Hyperplasia, and Lobular Carcinoma in Situ)
}

\author{
Rosen Triadı' nın (Tübüler Karsinom, Kolumnar Hücre Hiperplazi \\ ve Lobüler Karsinoma in Situ) Bir Parçası Olarak Taşlı Yüzük \\ Lobüler Karsinoma in Situ
}

Josko BEZIC, Dijana GUGIC

Clinical Hospital Split, Institute of Pathology, Split, CROATIA

\begin{abstract}
Objective: The association of tubular carcinoma, columnar cell lesions and lobular carcinoma in situ, also known as the "Rosen Triad", may be encountered in breast biopsies performed for evaluation of mammographically detected microcalcifications.

Case Report: A case in which tubular carcinoma and columnar cell hyperplasia were associated with a histologically unusual form of signet ring lobular carcinoma in situ is presented. Signet ring non-invasive lobular carcinoma is classified as high-grade lobular carcinoma in situ, but herein is associated with changes that belong to the molecular pathway of low-grade mammary neoplasia.

Conclusion: We reported the case of lobular carcinoma in situ associated with columnar cell hyperplasia and tubular carcinoma, in which the lobular carcinoma in situ was presented in a histologically unexpected form comprised predominantly of signet ring cells.
\end{abstract}

Key Words: Breast, Carcinoma, Signet ring cell, Carcinoma in situ
ÖZ

Amaç: "Rosen Triadı" olarak da bilinen tübüler karsinom, kolumnar hücre lezyonları ve lobüler karsinoma in situ birlikteliği, mamografik olarak saptanmış mikrokalsifikasyonların değerlendirilmesi için yapılan meme biopsilerinde görülebilir.

Olgu Sunumu: Tübüler karsinom ve kolumnar hücre hiperplazisi ile ilişkili, histolojik olarak olağan dışı bir taşlı yüzük lobüler karsinoma in situ vakası sunulmaktadır. Taşlı yüzük noninvaziv lobüler karsinom, yüksek dereceli lobüler karsinoma in situ olarak sınıflandırılmaktadır ancak burada düşük dereceli meme neoplazisinin moleküler yolağına ait değişikliklerle ilişkilidir.

Sonuç: Kolumnar hücre hiperplazisi ve tübüler karsinom ile ilişkili, histolojik olarak beklenmeyen bir şekilde baskın olarak taşlı yüzük hücrelerinden olușan, bir lobüler karsinoma in situ vakası sunduk.

Anahtar Sözcükler: Meme, Karsinom, Taşlı yüzük hücreli, Karsinoma in situ

\section{INTRODUCTION}

The widespread use of mammographic screening has called attention to columnar cell lesions, a histological finding commonly encountered in breast biopsies performed for evaluation of detected microcalcifications. Columnar cell lesions are histologically characterized by dilated terminal duct lobular units lined by epithelium showing columnar cell morphology, ranging from one or two layers of benign epithelium to stratified epithelium with or without atypia $(1,2)$. In the past, many investigators recognized these morphological changes under a variety of terms. Nowadays a practical classification system, which divides columnar cell lesions in three broad categories as columnar cell change

(Turk Patoloji Derg 2013, 29:134-137)

Received : 22.02.2012 Accepted : 19.04.2012
(CCC), columnar cell hyperplasia (CCH), and columnar cell change/hyperplasia with cytological atypia has been adopted. The World Health Organization has proposed the term flat epithelial atypia (FEA) for columnar cell change/ hyperplasia with atypia, with alternative designation of ductal intraepithelial neoplasia grade 1A (DIN 1A) $(1,3)$.

Rosen first observed frequent histological coexistence of tubular carcinoma (TC) and $\mathrm{CCH}$, with occasional association of lobular carcinoma in situ (LCIS) (4). The histological triad of TC, columnar cell lesions and LCIS is also known as the "Rosen Triad". Here we portray a case of "Rosen Triad" in which TC is associated with $\mathrm{CCH}$ and signet ring LCIS.

Correspondence: Josko BEZIC

Clinical Hospital Split, Institute of Pathology, Split, CROATIA

E-mail: jbezic@mefst.hr Phone: +38521556512 


\section{CASE REPORT}

A 75-year-old woman presented with suspicious microcalcifications in the right breast discovered by mammography, with no palpable abnormalities on physical examination. Ultrasound examination depicted a heterogeneous, hypoechogenic zone of $1 \mathrm{~cm}$ in diameter, with dorsal attenuations and ill-defined borders suggestive of carcinoma. Fine needle aspiration cytology showed only epithelial proliferation without atypia. Surgical excision of the lesion was recommended.

Surgical intraoperative biopsy of the detected abnormality was performed. On gross examination the tumor was an illdefined, grey-white mass measuring $1 \times 0.6 \mathrm{~cm}$, with firm consistency. Frozen section analysis rendered a diagnosis of invasive TC. Modified radical mastectomy with an axillary lymph node dissection followed.

Tissue was fixed in neutral buffered formalin and embedded in paraffin for routine histological examination. Slides were stained with hematoxylin and eosin with additional ER, PgR, CD10, p63, E-cadherin, and HER2/neu immunohistochemical analysis.

On histological examination, the tumor was composed of oval, focally angulated glands and few cords haphazardly distributed in fibrous stroma with an occasional microcalcification (Figure 1,2). A single layer of epithelial cells, with grade 1 nuclei and no mitoses, lined the tumor glands without visible myoepithelial layer on CD10 and p63 immunostains. This description was consistent with diagnosis of TC. In the carcinomatous tissue several dilated acini, lined with two to three layers of columnar cells without atypia, oriented perpendicularly to the basement membrane were seen, representing $\mathrm{CCH}$ (Figure 1,2). Adjacent to TC and foci of $\mathrm{CCH}$ a few dilated acini, colonized by small discohesive cells whose cytoplasms were eosinophilic or vacuolated, many with peripherally displaced nuclei, were seen (Figure 1, 3). Cells were immunohistochemically E-cadherin negative, which is consistent with the diagnosis of signet ring type LCIS.

Tubular carcinoma, CCH and LCIS cells were ER and PgR positive and HER2/neu negative. Neither residual breast tissue nor dissected axillary lymph nodes showed additional histological abnormalities.

\section{DISCUSSION}

The introduction of screening mammography in the early 1980s has dramatically influenced many aspects of breast surgical pathology. Compared to the pre-screening period, breast biopsies of screened abnormalities contain a greater

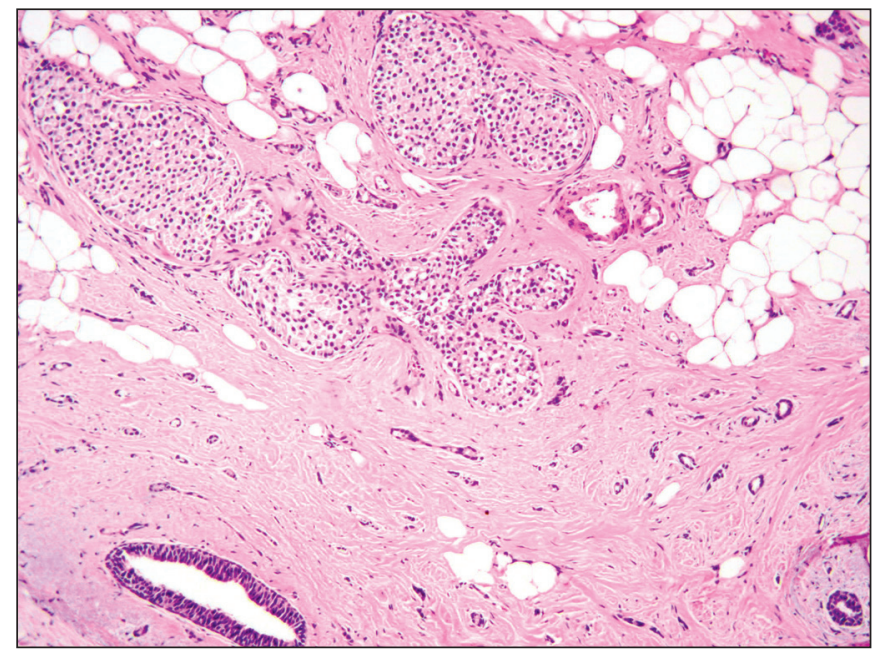

Figure 1: Breast tissue demonstrating signet ring LCIS, focus of $\mathrm{CCH}$, and tubular carcinoma in one area (H\&E, $\mathrm{x} 100)$.

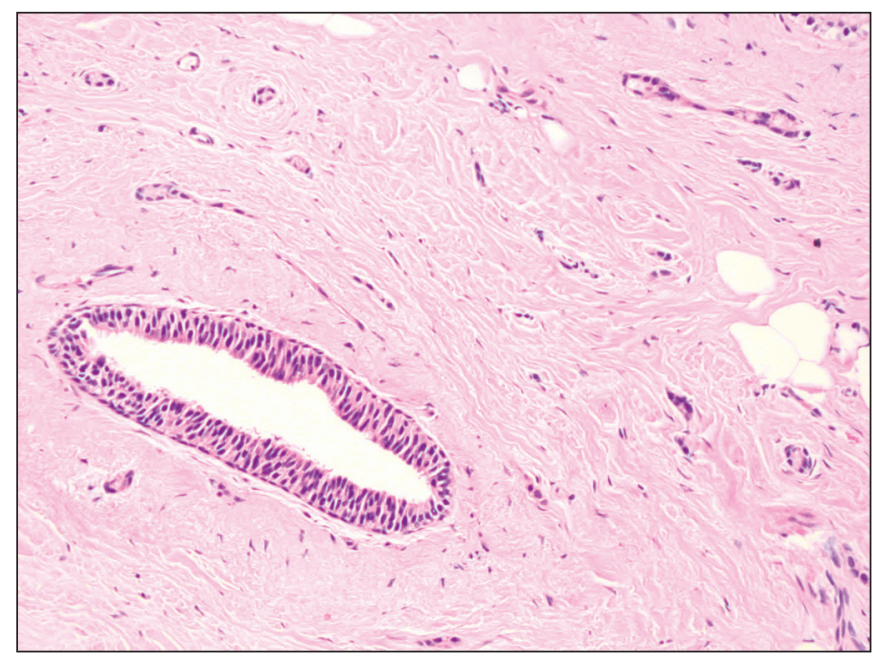

Figure 2: The focus of columnar cell hyperplasia surrounded by tubular carcinoma composed of angulated glands and few cords of neoplastic cells (H\&E, x200).

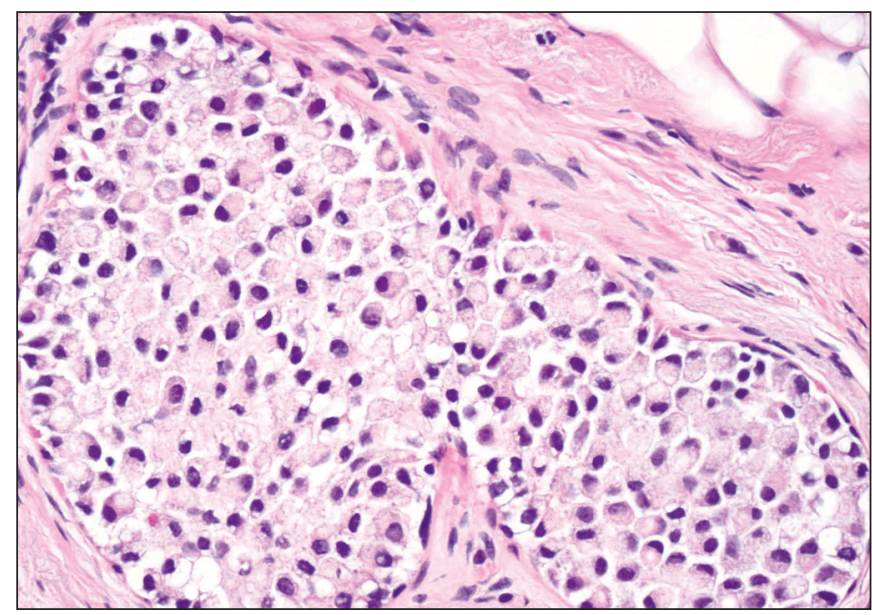

Figure 3: The lobular carcinoma in situ predominantly composed of signet ring cells ( $\mathrm{H} \& \mathrm{E}, \mathrm{x} 400)$. 
number of non-invasive breast cancers, small invasive breast cancers (T1a,b), and prognostically favorable histological types of invasive breast cancers. The widespread use of mammographic screening has also called attention to one other morphological change - the columnar cell lesion nowadays commonly encountered in breast core biopsies performed for evaluation of detected microcalcifications.

Columnar cell lesions are currently divided into three histologically well-defined categories: $\mathrm{CCC}, \mathrm{CCH}$, and FEA. Columnar cell change is histologically characterized by dilated acini lined by one or two layers of columnar epithelial cells oriented perpendicularly to the basement membrane, with apical snouts present along the luminal surface of the cells. Cells are regular in size and shape, and have uniform nuclei with inconspicuous nucleoli. Luminal secretion, with or without calcification, is usually present. In $\mathrm{CCH}$, more than two cell layers of columnar epithelial cells line the dilated acini, and cells have the same cytological features as those described in CCC. The proliferating cells may form small tufts or short micropapillae, and luminal secretion with calcification is common in CCH. In FEA, the columnar cells exhibit mild cytological atypia with round nuclei, visible nucleoli, and occasional mitotic figures, with loss of perpendicular orientation of the cells to the basement membrane (1-3).

Columnar cell lesions may be associated with a variety of other breast proliferative lesions (5). Rosen observed that patients with tubular carcinoma (TC) often had foci of $\mathrm{CCH}$, distributed in surrounding areas or even in the carcinomatous tissue, with occasional presentation of LCIS (4).

The frequency of associated changes is variable in the "Rosen Triad". In the series of 56 pure TCs, Abdel-Fatah et al. found a high prevalence of columnar cell lesions (95\%), and low prevalence of lobular neoplasia (LN) (16\%) (5). In a series of 86 TCs, reported by Brandt et al., some degree of columnar cell lesions was found in all cases, while LCIS was found in $53 \%$ of the cases (6). Fernández-Aguilar and coworkers found associated FEA in $47.8 \%$, and lobular intraepithelial neoplasia (LIN) in $17.4 \%$ of the 23 pure TC cases (7). Sahoo and Recant reported an additional case of TC associated with CCH and LCIS (8).

The identical chromosomal alterations frequently found in TC, CCC, and LCIS and in particular the complete or partial loss of 16q provide an additional link between these entities, which together with low-grade ductal carcinoma in situ belong to the molecular pathway of low-grade mammary neoplasia $(1,9)$.
At first glance our signet ring LCIS finding associated with premalignant and low grade malignant changes may look controversial. Lobular carcinoma in situ, composed predominantly of signet ring cells, is classified as high-grade LCIS (LIN 3) because of its higher frequency of associated invasive carcinoma at presentation, particularly lobular invasive carcinoma (10). However, we feel that designation of high-grade LCIS (LIN 3) in aforementioned context is predominantly based on the frequent association with invasive breast carcinoma, and not on the cell morphology itself. Tumor cells in presented case of LCIS resemble classic LCIS cells, but with prominent intracytoplasmic vacuoles and consecutive signet ring appearance. Pleomorphic LCIS (high grade LCIS, LIN 3), which may also be composed of signet ring cells, differs from classic LCIS. Pleomorphic LCIS shows significant nuclear atypia, cellular pleomorphism, presence of macro nucleoli, and occasional central necrosis $(11,12)$. None of these features were presented in our case of signet ring LCIS.

In conclusion, we reported the case of $\mathrm{TC}$ associated with CCH and LCIS, in which the later presented in a histologically unexpected form comprised predominantly of signet ring cells.

\section{REFERENCES}

1. Feeley L, Quinn CM: Columnar cell lesions of the breast. Histopathology 2008, 52:11-19

2. Schnitt SJ, Vincent-Salomon A: Columnar cell lesions of the breast. Adv Anat Pathol 2003, 10:113-124

3. Tavassoli FA, Hoefler H, Rosai J, Holland R, Ellis IO, Schnitt SJ, Boecker W, Heywang-Köbrunner SH, Moinfar F, Lakhani SR: Intraductal proliferative lesions. In: Tavassoli FA, Devilee P (Eds): World Health Organization Classification of Tumours: Pathology and Genetics of Tumours of the Breast and Female Genital Organs. Lyon, IARC Press, 2003, 63-73

4. Rosen PP: Columnar cell hyperplasia is associated with lobular carcinoma in situ and tubular carcinoma. Am J Surg Path 1999, 23:1561

5. Abdel-Fatah TM, Powe DG, Hodi Z, Lee AH, Reis-Filho JS, Ellis IO: High frequency of coexistence of columnar cell lesions, lobular neoplasia, and low grade ductal carcinoma in situ with invasive tubular carcinoma and invasive lobular carcinoma. Am J Surg Path 2007, 31:417-426

6. Brandt SM, Young GQ, Hoda SA: The "Rosen Triad": Tubular carcinoma, lobular carcinoma in situ, and columnar cell lesions. Adv Anat Pathol 2008, 15:140-146

7. Fernández-Aguilar S, Simon P, Buxant F, Simonart T, Noël JC: Tubular carcinoma of the breast and associated intra-epithelial lesions: A comparative study with invasive low-grade ductal carcinomas. Virchows Arch 2005, 447:683-687 
8. Sahoo S, Recant WM: Triad of columnar cell alteration, lobular carcinoma in situ and tubular carcinoma of the breast. Breast J 2005, 11:140-142

9. Brogi E, Murray MP, Corben AD: Lobular carcinoma, not only a classic. Breast J 2010, 16 (Suppl 1): S10-14

10. Bratthauer GL, Tavassoli FA: Lobular intraepithelial neoplasia: Previously unexplored aspects assessed in 775 cases and their clinical implications. Virchows Arch 2002, 440:134-138
11. Chivukula M, Haynik DM, Brufsky A, Carter G, Dabbs DJ: Pleomorphic lobular carcinoma in situ (PLCIS) on breast core needle biopsies: clinical significance and immunoprofile. Am J Surg Pathol 2008, 32:1721-1726

12. Fadare O: Pleomorphic lobular carcinoma in situ of the breast composed almost entirely of signet ring cells. Pathol Int 2006, $56: 683-687$ 